\title{
外部気流を利用した大空間構造物の換気・温熱特性に関する研究 A STUDY ON THE CHARACTERISTICS OF AIR VENTILATION AND THERMAL CONDITION IN A LARGE INDOOR SPACE WITH OPENINGS
}

\author{
諏訪 好 英*，表 佑太郎**，本 間 義 教*，大高一 博***，橋 本 直 樹*** \\ Yoshihide SUWA, Yutaro OMOTE, Yoshinori HOMMA, \\ Kazuhiro OTAKA and Naoki HASHIMOTO
}

\begin{abstract}
An adoption of natural ventilation system is one of the most effective strategies on energy concervations for air-conditioning systems in large indoor spaces. Characteristics of air ventilation and thermal condition in a hemispherical large indoor stadium with openings were studied using numerical analysis technique based on the BFC (Boundary Fitted Coordinate system) calculation.

As the result of the study, the following conclusions were drawn; (1) Air flow around a hemispherical dome makes negative pressure field on the top of the roof. (2) Openings arranged on the roof act as an effective exhaust. Enough air exchange rate was obtained in the stadium when the openings were arranged on side walls and top of the roof. (3) Natural ventilation which is obtained using these openings enables to remove heated air caused by the solar radiation, and energy for air-conditionings will be concerved during spring and autumn.
\end{abstract}

Keywords : large indoor space, natural ventilation system, characteristic of thermal condition, numerical analysis, $B F C$, standard $K-\varepsilon$ turbulence model

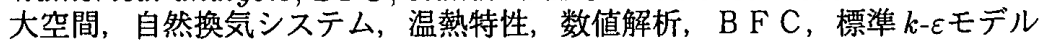

\section{1.はじめに}

スポーツや展示会, コンサートなど各種イベントに対応 した大型の多目的屋内スタジアムが，近年，各地で建設さ れるようになった。これらのいわゆる大空間構造物では, 内部容積や天井高が大きいこと，居住域と非居住域とが同 一の屋内空間に湜在することなどに起因して，一般の建築 物とは大きく異なる屋内温熱特性を示す。これまで, 空調 設備設計の立場からは大空間構造物に対応した熱負荷計算 手法の開発1),2),3)や空調制御方法の検討が，また温熱・気 流解析の立場からは温度成層の影響を考慮した非等温乱流 モデルによる研究4)や対流・放射連成解析5)などさまざま な試みが行われている。

一方，これら大空間構造物の屋内環境制御には，大容量 の空調・送風設備が必要であり，その消費エネルギーも膨 大なものとなる。このため大空間構造物の屋内環境計画に は，経済性や外部環境への影響などについてもさまざまな 配虑が必要である。

大空間構造物の空調・送風消費エネルギーを削減するひ とつの方法として，自然換気の利用が考えられる。自然換 気を効果的に利用できれば，屋内換気に必要な送風エネル
ギーの大幅な削減が可能である。またスポーツ観戦や大型 イベント会場として使用される屋内スタジアムでは人体発 熱による熱負荷が大きく，特にドーム構造のスタジアムで は居住域に対する天井面の輻射形態係数が大きいため，日 射などの影響により年間を通じて冷房が必要となる場合も 多い。局所的な居住域空調と併用して自然換気を行うシス テムでは天井面付近に形成される成層的な熱だまりの除去 が可能となるとともに，外気冷房的な効果が得られ，季節 によっては空調エネルギーを削減できる可能性も考えられ る。

建築物の自然換気特性には，外部気流により引き起こさ れる建築物周辺気流の状態と開口部の設置位置とが大きく 関与する。また本研究で対象とするような大空間構造物で は，自然換気により形成される屋内の気流状態の把握も重 要な課題である。実験的にこれらの特性を検討する場合， 模型則や風洞寸法の関係から，屋内気流の検討には縮尺 $1 / 40 \sim 1 / 60$, 周辺気流の検討には縮尺 $1 / 200 \sim 1 / 300$ 程 度の模型が通常用いられており，屋内外の現象が同時に作 用するようなこの種の問題に対応することは困難である。 本研究では気流および熱輸送の数值解析手法を用いて屋
* 侏大林組 技術研究所

***株大林組 技術研究所・工博

****株) 日建設計
Technical Research Inst., OBAYASHI Corp

Technical Research Inst., OBAYASHI Corp., Dr. Eng.

Nikken Sekkei 
内外の現象解析を同時に実施し，外部気流を利用した大 空間構造物の自然換気特性, 温熱環境特性について考察し た。本報では屋内外気流解析の概要と, これを用いて実施 した大空間構造物の自然換気特性, 温熱環境特性に関する 検討結果を報告する。

\section{2. 数值解析手法}

\section{1 基磴方程式}

本研究では, 数值解析手法を用いて建築物周辺気流, 屋 内の自然換気特性および屋内温熱特性の考察を行った。特 に屋内の換気，温熱特性の検討には，日射その他の熱的外 部条件や空調, 照明, 人体などからの発熱を考慮した熱対 流連成解析を行うこととした。したがって想定した基礁方 程式は，流体の運動量方程式，連続の式および熱量輸送に 関するエネルギー方程式から構成される。

ここでは曲面的なドーム構造を対象とするため, 計算に は一般曲線座標系を用いた。乱流モデルとして標準 $k-\varepsilon モ$ テル6)を採用し，一般曲線座標系に写像変換すると，基磪 方程式は以下のように表される[注1]。

$$
\begin{aligned}
& \frac{\partial \rho}{\partial t}+\frac{1}{|J|} \frac{\partial|J| \rho U_{i}}{\partial \xi_{i}}=0 \\
& \frac{\partial \rho u_{i}}{\partial t}+\frac{1}{|J|} \frac{\partial|J| U_{j} \rho u_{i}}{\partial \xi_{j}}=-\frac{\partial \xi_{j}}{\partial x_{i}} \frac{\partial p}{\partial \xi_{j}} \\
& +\frac{1}{|J|} \frac{\partial}{\partial \xi_{j}}\left\{2|J| \frac{\partial \xi_{j}}{\partial x_{k}}\left(\mu+\mu_{T}\right) S_{i k}\right\}-R_{i}+\rho g_{i} \\
& \frac{\partial \rho h}{\partial t}+\frac{1}{|J|} \frac{\partial|J| \rho U_{i} h}{\partial \xi_{i}} \\
& =\frac{1}{|J|} \frac{\partial}{\partial \xi_{i}}\left\{|J| q_{i j}\left(\lambda+C_{p} \frac{\mu_{T}}{P r t}\right) \frac{\partial T}{\partial \xi_{j}}\right\}+\dot{Q} \\
& \mu_{T}=C_{\mu} \rho \frac{k^{2}}{\xi} \\
& p_{0}=\frac{\gamma_{c}-\tilde{I}}{\gamma_{c}} \rho h \\
& \frac{\partial \rho k}{\partial t}+\frac{1}{|J|} \frac{\partial|J| U_{i} \rho k}{\partial \xi_{i}} \\
& =\frac{1}{|J|} \frac{\partial}{\partial \xi_{i}}\left\{|J| q_{i j}\left(\mu+\frac{\mu_{T}}{\sigma_{k}}\right) \frac{\partial k}{\partial \xi_{j}}\right\} \\
& +G s+G_{T}-\rho \varepsilon \\
& \frac{\partial \rho \varepsilon}{\partial t}+\frac{1}{|J|} \frac{\partial|J| U_{i} \rho \varepsilon}{\partial \xi_{i}} \\
& =\frac{1}{|J|} \frac{\partial}{\partial \xi_{i}}\left\{|J| q_{i j}\left(\mu+\frac{\mu_{T}}{\sigma_{\varepsilon}}\right) \frac{\partial \varepsilon}{\partial \xi_{j}}\right\} \\
& +C_{1} \frac{\varepsilon}{k}\left(G s+G_{T}\right)\left(1+C_{3} R_{f}\right)-C_{2} \frac{\rho \varepsilon^{2}}{k} \\
& U_{i}=\frac{\partial \xi_{i}}{\partial x_{j}}, \quad J \equiv \frac{\partial\left(x_{1}, x_{2}, x_{3}\right)}{\partial\left(\xi_{1}, \xi_{2}, \xi_{3}\right)} \\
& S_{i, k}=\frac{1}{2}\left(\frac{\partial \xi_{l}}{\partial x_{k}} \frac{\partial u_{i}}{\partial \xi_{l}}+\frac{\partial \xi_{l}}{\partial x_{i}} \frac{\partial u_{k}}{\partial \xi_{l}}\right), \quad q_{i j}=\frac{\partial \xi_{i}}{\partial x_{k}} \frac{\partial \xi_{j}}{\partial x_{k}} \\
& G_{T}=\frac{\mu_{T}}{\rho \sigma_{T}} \frac{1}{|J|}\left\{g_{i}\left(\frac{\partial \xi_{j}}{\partial x_{i}} \frac{\partial|J| \rho}{\partial \xi_{j}}\right)\right\}, \\
& G s=2 \mu_{T} S_{i j} \frac{\partial \xi_{l}}{\partial x_{j}} \frac{\partial u_{i}}{\partial \xi_{l}}, \quad R_{f}=-\frac{G_{T}}{G s+G_{T}}
\end{aligned}
$$

なお運動量方程式とエネルギー方程式との連成計算のた

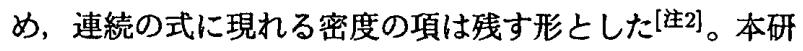

究では流体運動に伴う密度変化を考虑するような急峻な現 象を対象とするわけではない。密度の計算は浮力効果を評 価する目的のみに限定することとし，ここでは密度が温度 の関数として一意に決定するものと仮定した[注3]。

\section{2 基礎方程式の敨教化}

(2.2.a) タトリックと基礕方程式の空間への離散化

本研究で用いた数值解析手法には, スタッガート変数配 置による離散化方程式を用いた。以下の展開のため, 変換 のメトリックはあらかじめ図 1 -a) に示すような定義点に 配置することとする。セル界面におけるメトリックは次の ように計算する。たとえば $\xi$ 一定面において,

$$
\begin{aligned}
& \left(|J| \frac{\partial \xi}{\partial x}\right)_{i+1 / 2, j, k} \\
& =\frac{1}{4}\left\{\left(y_{i+1, j+1, k}+y_{i+1, j+1, k+1}-y_{i+1, j, k}-y_{i+1, j, k+1}\right)\right. \\
& \quad \times\left(z_{i+1, j, k+1}+z_{i+1, j+1, k+1}-z_{i+1, j, k}-z_{i+1, j+1, k}\right) \\
& -\left(y_{i+1, j, k+1}+y_{i+1, j+1, k+1}-y_{i+1, j+1, k}-y_{i+1, j+1, k}\right) \\
& \left.\quad \times\left(z_{i+1, j+1, k}+z_{i+1, j+1, k+1}-z_{i+1, j, k}-z_{i+1, j, k+1}\right)\right\}
\end{aligned}
$$

ここに各セルでの変換の恒等式,

$$
\frac{\partial}{\partial \xi_{i}}\left(|J| \frac{\partial \xi_{i}}{\partial x_{j}}\right)=0
$$

が満足される。(9) 式は一様流の連続条件と同俌であり, 連 続の式を厳密に扱うためには (9) 式を満足することが必要 である。

基礎方程式 (1) 〜 (7) の離散化には図 1-b) に示すよ うなスタッガート変数配置を用いた。すなわち従属変数 $\rho, \rho u_{i}, p, \rho h, \rho k お よ ひ ゙ \varepsilon$ をセル中心で定義し，特性速度と してセル界面に定義した反変成分 $|J| U_{i}$ を使用する。特性 速度に反変成分を用いると, 各方程式の離散化に関して保 存型の展開が容易となる。

各方程式を空間について離散化すると次式を得る。

$$
\begin{aligned}
& \left(\frac{\partial \phi}{\partial t}\right)_{i, j, k} \\
& +\frac{1}{|J|_{i, j, k}}\left(|J|_{i+1 / 2, j, k} F_{i+1 / 2, j, k}-|J|_{i-1 / 2, j, k} F_{i-1 / 2, j, k}\right. \\
& \quad+|J|_{i, j+1 / 2, k} F_{i, j+1 / 2, k}-|J|_{i, j-1 / 2, k} F_{i, j-1 / 2, k} \\
& \left.+|J|_{i, j, k+1 / 2} F_{i, j, k+1 / 2}-|J|_{i, j, k-1 / 2} F_{i, j, k-1 / 2}\right) \\
& +S_{i, j, k}=0
\end{aligned}
$$

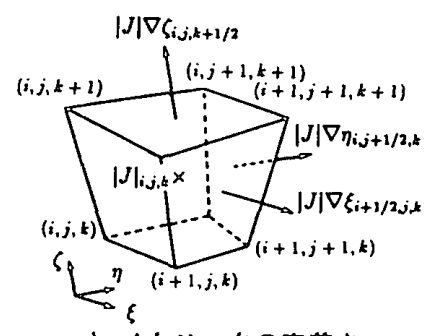

a) タ゚トリックの定筑点

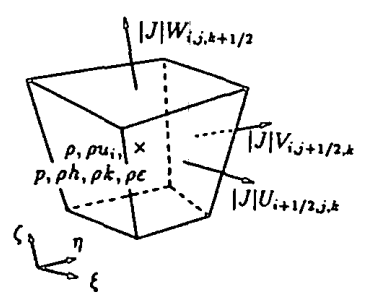

b) 夜数の定䄈点
図 1 メトリックと变数の定義点 
ここにめは各方程式の従属変数，Fはセル界面でのフラッ クス，Sは生成消隇項である。フラックス F は対流による 成分 $F_{C}$ と搪散による成分 $F_{D}$ の和として表され，それぞ れ以下の形で展開できる。たとえば,

$$
\begin{aligned}
& F_{i+1 / 2, j, k}^{C}=\langle\rho \phi\rangle_{i+1 / 2, j, k} U_{i+1 / 2, j, k} \\
& F_{i+1 / 2, j, k}^{D}=-\Gamma_{i+1 / 2, j, k}\left\{\left(q_{11}\right)_{i+1 / 2, j, k}\left(\phi_{i+1, j, k}-\phi_{i, j, k}\right)\right. \\
& \quad+\frac{1}{2}\left(q_{12}\right)_{i+1 / 2, j, k}\left(\phi_{i+1 / 2, j+1, k}-\phi_{i+1 / 2, j-1, k}\right) \\
& \left.\quad+\frac{1}{2}\left(q_{13}\right)_{i+1 / 2, j, k}\left(\phi_{i+1 / 2, j, k+1}-\phi_{i+1 / 2, j, k-1}\right)\right\}
\end{aligned}
$$

$\langle\rho \phi\rangle$ はセル界面での值を示すが, 図 1-b)にも示したよう にセル界面では独立変数が定義されていない。隣接点から の内挿補間に 3 次精度 QUICK 法 ${ }^{7)}$ を用いると， $\langle\rho \phi\rangle$ は以 下のように表される。

$$
\begin{gathered}
U_{i+1 / 2, j, k} \geqq 0: \quad\langle\rho \phi\rangle_{i+1 / 2, j, k}=\frac{1}{2}\left\{(\rho \phi)_{i, j, k}+(\rho \phi)_{i+1, j, k}\right\} \\
-\frac{1}{8}\left\{(\rho \phi)_{i+1, j, k}-2(\rho \phi)_{i, j, k}+(\rho \phi)_{i-1, j, k}\right\} \quad\left(13_{-} 1\right) \\
U_{i+1 / 2, j, k}<0: \quad\langle\rho \phi\rangle_{i+1 / 2, j, k}=\frac{1}{2}\left\{(\rho \phi)_{i, j, k}+(\rho \phi)_{i+1, j, k}\right\} \\
-\frac{1}{8}\left\{(\rho \phi)_{i+2, j, k}-2(\rho \phi)_{i+1, j, k}+(\rho \phi)_{i, j, k}\right\} \quad\left(13_{-} 2\right)
\end{gathered}
$$

\section{(2.2.b) 基礎方程式の時間方向への離散化}

本研究では定常的な特性の検討を目的としている。ここ では形式的に時間依存解法を用いたが，時間積分の過程に おいて現象変化が定常的となった時点での解を定常解とし て扱うこととした。Euler 陽解法により基礎方程式を時間 方向に離散化すると, 連続の式, 運動量方程式およびその 他の輸送方程式はそれぞれ以下のように展開できる。

$$
\begin{aligned}
& \frac{\rho^{n}-\rho^{n-1}}{\Delta t}+\frac{1}{|J|}\left(\frac{\partial|J| \rho^{n} U_{i}^{n+1}}{\partial \xi_{i}}\right)=0 \\
& \frac{\left(\rho u_{i}\right)^{n+1}-\left(\rho u_{i}\right)^{n}}{\Delta t}+\frac{1}{|J|} \frac{\partial|J| U_{j}^{n}\left(\rho u_{i}\right)^{n}}{\partial \xi_{j}}=-\frac{\partial \xi_{j}}{\partial x_{i}} \frac{\partial p^{n+1}}{\partial \xi_{j}} \\
& +\frac{1}{|J|} \frac{\partial}{\partial \xi_{j}}\left\{2|J| \frac{\partial \xi_{j}}{\partial x_{k}}\left(\mu+\mu_{T}\right) S_{i k}^{n}\right\}-R_{i}^{n+1}+\rho^{n} g_{i} \\
& \frac{(\rho \phi)^{n+1}-(\rho \phi)^{n}}{\Delta t}+\frac{1}{|J|} \frac{\partial|J| U_{i}^{n+1}(\rho \phi)^{n}}{\partial \xi_{i}} \\
& =\frac{1}{|J|} \frac{\partial}{\partial \xi_{i}}\left\{|J| q_{i j} \Gamma \frac{\partial \phi^{n}}{\partial \xi_{j}}\right\}+S^{n}
\end{aligned}
$$

ここで計算の簡略化のため, 連続式の密度の時間微分項お よび渦動粘性係数については，1 ステップ前の值を代用し て用いることとした。速度場, 圧力場の補正計算において 半陰解法的な扱いを行う場合には，エネルギー方程式，乱 流諸量の輸送方程式の計算を反復計算に組み込み，その時 点での值を同時に求めることも可能である。しかし先述し たように，ここでは過渡的な応答を問題とするわけではな いので，時間ステップ内でのこれら諸量の扱いを反復計算 に組み込まなくても十分であると判断した[注4]。

\section{3 運動量方程式の解法}

運動量方程式の解法には SIMPLE 法8)を用いた。まず
各方向の成分に対する運動量方程式を圧力勾配項 $g^{u_{i}}$ とそ の他の空間微分項および外力項 $f^{u_{i}}$ に分けて考える。

$$
\frac{\partial \rho u_{i}}{\partial t}=f^{u_{i}}\left(\rho^{n}, u_{j}^{n}, U_{j}^{n}\right)+g^{u_{i}}\left(p^{n}\right)
$$

さらに次式,

$$
\frac{\partial|J| \rho U_{i}}{\partial t}=|J| \frac{\partial \xi_{i}}{\partial x_{j}} \frac{\partial \rho u_{j}}{\partial t}=|J| \frac{\partial \xi_{i}}{\partial x_{j}}\left(f^{u_{j}}+g^{u_{j}}\right)
$$

により物理速度を反変速度に変換したものを $(10),(15)$ 式に従って離散化し, $p^{n+1}$ を 1 ステップ前の圧力 $p^{n}$ に置 き換えると反変速度の仮定值 $U^{*}, V^{*}, W^{*}$ について次式を 得る。

$$
\begin{aligned}
& \left(\rho U^{*}\right)_{i+1 / 2, j, k}^{n+1}=(\rho U)_{i+1 / 2, j, k}^{n} \\
& +\Delta t\left[\left(\xi_{x} f^{u}\right)_{i+1 / 2, j, k}+\left(\xi_{y} f^{v}\right)_{i+1 / 2, j, k}+\left(\xi_{z} f^{w}\right)_{i+1 / 2, j, k}\right. \\
& -\left\{\left(q_{11}\right)_{i+1 / 2, j, k}\left(p_{i+1, j, k}^{n}-p_{i, j, k}^{n}\right)\right. \\
& +\frac{1}{2}\left(q_{12}\right)_{i+1 / 2, j, k}\left(p_{i+1 / 2, j+1, k}^{n}-p_{i+1 / 2, j-1, k}^{n}\right) \\
& \left.\left.+\frac{1}{2}\left(q_{13}\right)_{i+1 / 2, j, k}\left(p_{i+1 / 2, j, k+1}^{n}-p_{i+1 / 2, j, k-1}^{n}\right)\right\}\right] \quad(19-1) \\
& \left(\rho V^{*}\right)_{i, j+1 / 2, k}^{n+1}=(\rho V)_{i, j+1 / 2, k}^{n} \\
& +\Delta t\left[\left(\eta_{x} f^{u}\right)_{i, j+1 / 2, k}+\left(\eta_{y} f^{v}\right)_{i, j+1 / 2, k}+\left(\eta_{z} f^{w}\right)_{i, j+1 / 2, k}\right. \\
& -\left\{\frac{1}{2}\left(q_{21}\right)_{i, j+1 / 2, k}\left(p_{i+1, j+1 / 2, k}^{n}-p_{i-1, j+1 / 2, k}^{n}\right)\right. \\
& +\left(q_{22}\right)_{i, j+1 / 2, k}\left(p_{i, j+1, k}^{n}-p_{i, j, k}^{n}\right) \\
& \left.\left.+\frac{1}{2}\left(q_{23}\right)_{i, j+1 / 2, k}\left(p_{i, j+1 / 2, k+1}^{n}-p_{i, j+1 / 2, k-1}^{n}\right)\right\}\right] \quad(19-2) \\
& \left(\rho W^{*}\right)_{i, j, k+1 / 2}^{n+1}=(\rho W)_{i, j, k+1 / 2}^{n} \\
& +\Delta t\left[\left(\zeta_{x} f^{u}\right)_{i, j, k+1 / 2}+\left(\zeta_{y} f^{v}\right)_{i, j, k+1 / 2}+\left(\zeta_{z} f^{w}\right)_{i, j, k+1 / 2}\right. \\
& -\left\{\frac{1}{2}\left(q_{31}\right)_{i, j, k+1 / 2}\left(p_{i+1, j, k+1 / 2}^{n}-p_{i-1, j, k+1 / 2}^{n}\right)\right. \\
& +\frac{1}{2}\left(q_{32}\right)_{i, j, k+1 / 2}\left(p_{i, j+1, k+1 / 2}^{n}-p_{i, j-1, k+1 / 2}^{n}\right) \\
& \left.\left.+\left(q_{33}\right)_{i, j, k+1 / 2}\left(p_{i, j, k+1}^{n}-p_{i, j, k}^{n}\right)\right\}\right]
\end{aligned}
$$

特性速度と従属変数の定義点はスタッガートに配置されて いるので，(19-1) (19-3) 式では $f^{u_{i}}$ については (11) (13-2) 式により内挿補間し， $g^{u_{i}}$ は界面で直接計算するこ ととした。

本来の運動量方程式と (19-1) (19-3) 式のそれぞれ対 応する項の差をとり, 速度と圧力の補正量 $U^{C}, \delta p$

$$
\begin{aligned}
& U^{n+1}=\left(U^{*}\right)^{n+1}+U^{C} \\
& p^{n+1}=p^{n}+\delta p
\end{aligned}
$$

についてまとめると，以下のような速度補正式を得る。

$$
\begin{aligned}
\rho U^{C}= & (\rho U)^{n+1}-\left(\rho U^{*}\right)^{n+1} \\
& =-\Delta t\left(q_{11} \frac{\partial \delta p}{\partial \xi}+q_{12} \frac{\partial \delta p}{\partial \eta}+q_{13} \frac{\partial \delta p}{\partial \zeta}\right) \\
\rho V^{C}= & (\rho V)^{n+1}-\left(\rho V^{*}\right)^{n+1}
\end{aligned}
$$




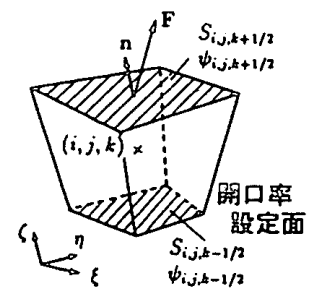

a）副セルへの開口率の設定

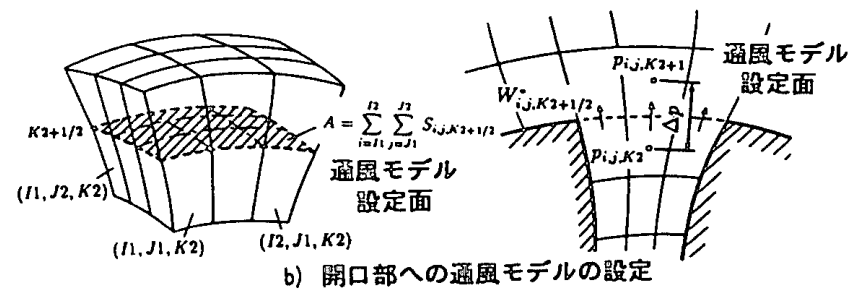

図 2 開口部への 2 㮐類の天デルの設定

$$
\begin{aligned}
& =-\Delta t\left(q_{21} \frac{\partial \delta p}{\partial \xi}+q_{22} \frac{\partial \delta p}{\partial \eta}+q_{23} \frac{\partial \delta p}{\partial \zeta}\right) \\
\rho W^{C} & =(\rho W)^{n+1}-\left(\rho W^{*}\right)^{n+1} \\
& =-\Delta t\left(q_{31} \frac{\partial \delta p}{\partial \xi}+q_{32} \frac{\partial \delta p}{\partial \eta}+q_{33} \frac{\partial \delta p}{\partial \zeta}\right)
\end{aligned}
$$

(22-1) ～(22-3) 式を連続の式に代入して, 王力補正式が 次のように求まる。

$$
\begin{aligned}
& \frac{1}{|J|}\left[\frac{\partial}{\partial \xi}\left\{|J|\left(q_{11} \frac{\partial \delta p}{\partial \xi}+q_{12} \frac{\partial \delta p}{\partial \eta}+q_{13} \frac{\partial \delta p}{\partial \zeta}\right)\right\}\right. \\
& +\frac{\partial}{\partial \eta}\left\{|J|\left(q_{21} \frac{\partial \delta p}{\partial \xi}+q_{22} \frac{\partial \delta p}{\partial \eta}+q_{23} \frac{\partial \delta p}{\partial \zeta}\right)\right\} \\
& \left.\quad+\frac{\partial}{\partial \zeta}\left\{|J|\left(q_{31} \frac{\partial \delta p}{\partial \xi}+q_{32} \frac{\partial \delta p}{\partial \eta}+q_{33} \frac{\partial \delta p}{\partial \zeta}\right)\right\}\right] \\
& =\frac{\rho^{n}-\rho^{n-1}}{(\Delta t)^{2}}+\frac{1}{\Delta t|J|} \\
& \times\left\{\frac{\partial|J|\left(\rho U^{*}\right)^{n+1}}{\partial \xi}+\frac{\partial|J|\left(\rho V^{*}\right)^{n+1}}{\partial \eta}+\frac{\partial|J|\left(\rho W^{*}\right)^{n+1}}{\partial \zeta}\right\}
\end{aligned}
$$

SIMPLE 法による速度補正は (23) 式および (22-1) (223) 式から計算した $U^{C}, V^{C}, W^{C}$ と，(19-1) （19-3)によ り計算した $U^{*}, V^{*}, W^{*} に よ り$ 行う。また圧力については 瑷和係数 $\alpha_{p}$ を用いて，次式により補正を行う。

$$
p^{n+1}=p^{n}+\alpha_{p} \delta p
$$

本研究では, 以下のような手順により方程式系の計算を 行うこととした。すなわち,

(I) 1 ステップ前の圧力を推定值として, (19-1) (19-3) 式により仮の反变速度を求める。

(II) (20) 〜 (24) 式を用いて SIMPLE 法のアルゴリズムに より速度および仕力補正の収束計算を行う。ただし密度 の時間微分項および渦動粘性係数については，1ステッ プ前の値を代用する。

(III) (I),(II) の手順によって得られた反変成分を, 次の時 間ステップのため物理速度に梁換しておく。変換は次式 による。

$$
\left(\rho u_{i}\right)^{n+1}=\frac{x_{i}}{\xi_{j}}\left(\rho U_{j}\right)^{n+1}
$$

(IV) (I),(II) の手順により求めた反変速度を用いて, エネ ルギー方程式および $k, \varepsilon$ の輸送方程式を解き，1 ステッ プ分の時間積分を終了する。

なお (23) 式のマトリクス計算には 5 項行列の解法を基本 とし、これを 3 次元方向にスィープする方法を用いた。

\section{4 開口部のモデル化}

本研究では外部気流を利用した自然換気特性の考察を目 的としているため, 屋内気流と屋外気流とを同時に解析す ることが必要となる。ただし屋内と屋外の空間は, 解析対 象領域に比へてかなり小さな開口部を介して連結されるこ ととなる。このような場合, 空間での計算格子分割幅と開 口部での分割幅との間に大きなスケール差を生じることと なり，そのままの形で開口部をモテルに再現することは困 難となる。ここでは開口部分のセル界面における開口率と 流量係数とを用いて次のように通風特性をモテル化した。

開口部での流量係数が既知である場合, 開口部分に相当 する計算セル界面での開口率としてこれを与える方法が考 えられる。しかしここで対象とする系では, 開口部に相当 する計算セル界面の面積も実際の開口面積とは一致してい ないため, 開口面積比としての開口率と流量係数の表現と しての開口率とを同時に扱うと, 計算上の開口率はかなり 小さな值となる。計算安定性の面などから開口率のみによ る通風特性のモテル化には限界があるものと考え, 流量係 数の扱いは別途モデル化して計算に組み込むこととした。 以下に開口面積比と通風特性についてのモテル化の方法を 示す。

(2.4.a) 開口率による開口面積比の表現

解析対象モデルのセル界面の面積と実際の開口面積との違 いについては，開口率によるモデル化を行った。図 $2-\mathrm{a}$ ) に示すような開口部分で，セル界面に開口率 $\psi$ が与えられ たものとすると, 基礎方程式の移流項を計算する際, セル を通過するフラックスは次式で評価される。

$$
\begin{aligned}
\left\{\int_{S_{i, j, k-1 / 2}}\right. & \left.-\int_{S_{i, j, k+1 / 2}}\right\} \mathbb{F} \cdot \mathbf{n} d s \\
& =\psi_{i, j, k-1 / 2}(\mathbb{F} \cdot \mathbf{n} S)_{i, j, k-1 / 2} \\
& -\psi_{i, j, k+1 / 2}(\mathbb{F} \cdot \mathbf{n} S)_{i, j, k+1 / 2}
\end{aligned}
$$

実際の開口面積に対する解析モデルの開口面皘の比として 開口率を定義すれば, 压力補正アルゴリズムにおいて, 界 面の前後には実際の開口面積に相当する圧力差を生じる。 ただしここで得られる王力差は, 流量係数 $\alpha=1.0$ を仮定 した場合に相当する。

(2.4.b) 通風特性を考慮した流量係数の扱い

図 2-b)に示すような開口部において，通風モテルにお ける通風量 $Q_{t r}$ と王力差との関係に (2.4.a) で示した開口 率を考應すると，次式が得られる。 


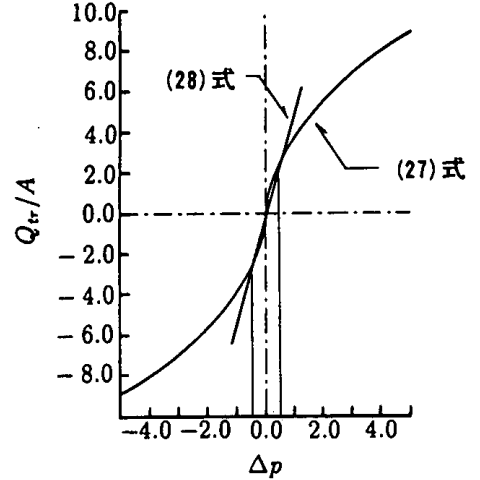

図 3 通風モデルの $\Delta p-Q_{f}$ 特性

$$
\begin{aligned}
Q_{t r}=\alpha & \Delta p \sqrt{\frac{2 g}{\gamma|\Delta p|}} \\
& \times\left\{\sum_{i=I 1}^{I 2} \sum_{j=J 1}^{J 2}\left(\psi_{i, j, K 2+1 / 2} S_{i, j, K 2+1 / 2}\right)\right\}
\end{aligned}
$$

$\Delta p$ については，開口率 $\psi$ を設定した界面中央の両側にあ るセル中心値から評価することとする。

各時間ステップにおける運動量方程式の計算を終了した 時点，すなわち 2.3 節の (I) を終了した時点では $\Delta p$ には 流量係数の影響が考慮されていない。このため (27) 式に よる速度補正を，2.3節の (II) に示されている反復アルゴ リズムに組み込んだ。すなわち本モデルを設定した界面に ついては (24) 式による圧力補正と (27) 式による通風量計 算とを反復し，速度補正を行わない。この方法によればそ の時点での連続の式が満足されない場合を生じるが，これ に続く時間ステップでは新たに補正した速度，王力状態に 基つきき計算を進めることとなり，時間の更新に伴って質量 保存が達成されることになる。

なお図 3 に示すように, $\Delta p \simeq 0.0$ の近傍では $\Delta p-Q_{t r}$ の 特性を表す曲線は勾配無限大に漸近する。本モデルでは圧 力差から通風量の計算を行うので, 压力差の絶対値が小さ い場合には反復計算の過程で計算不安定を引き起こすこと も予測される。このため $\Delta p$ が \pm 0.5 の範囲では直線近似を 適用し，(27) 式の代わりに次式を用いることとした。

$$
\begin{aligned}
Q_{t r} & =\left(Q_{2}-Q_{1}\right) \Delta p+Q_{1} \\
Q_{1} & =-q \sqrt{\frac{g}{\gamma}}\left\{\sum_{i=I 1}^{I 2} \sum_{j=J 1}^{J 2}\left(\psi_{i, j, K 2+1 / 2} S_{i, j, K 2+1 / 2}\right)\right\} \\
Q_{2} & =q \sqrt{\frac{g}{\gamma}}\left\{\sum_{i=I 1}^{I 2} \sum_{j=J 1}^{J 2}\left(\psi_{i, j, K 2+1 / 2} S_{i, j, K 2+1 / 2}\right)\right\}
\end{aligned}
$$

本モデルでは通風量の評価を開口単位で行うが, 開口部 が複数の計算セルから構成されている場合には速度分布を 再現する必要がある。ここでは，運動量方程式を計算した 時点での仮の反変速度のプロファイルを保存する形で通風 量を一致させることとした。すなわちセル界面での反変速 度 $\widetilde{W}$ は次式により補正される。

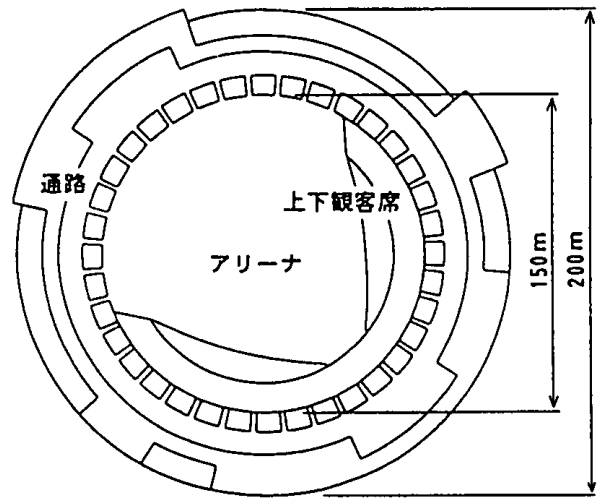

a) 虽内平面图

\begin{tabular}{|c|c|}
\hline 7 & 建究物概要 \\
\hline 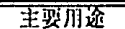 & 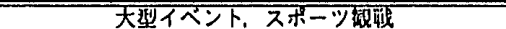 \\
\hline 双容微客数 & 5 万人 \\
\hline 趣案物規掑 & 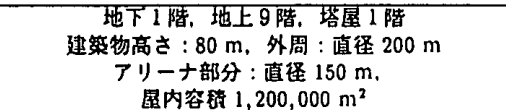 \\
\hline 茎造 & 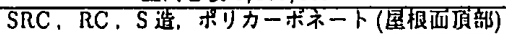 \\
\hline
\end{tabular}

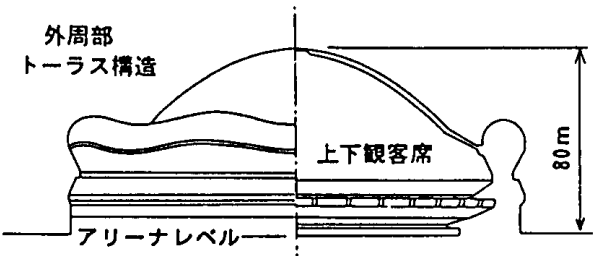

b) 立面图

図 4 対象とした建築物

表 1 対象建築物の概要

$\widetilde{W}_{i, j, K 2+1 / 2}=W_{i, j, K 2+1 / 2}^{*} Q_{t r}$

$$
/\left\{\sum_{i=I 1}^{I 2} \sum_{j=J 1}^{J 2}\left(W_{i, j, K 2+1 / 2}^{*} S_{i, j, K 2+1 / 2}\right)\right\}
$$

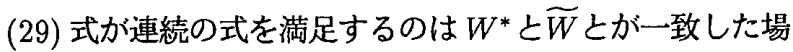
合であり，その時点で通風量と印力差との関係も同時に満 足される。

本モデルによる計算では，急峻な速度変化に伴う圧力勾 配の急激な立ち上がりを時間方向に緩和する効果が得られ るため，流量係数がさい場合や，通風量に応じて流量係 数か変化するような場合についても良好な計算安定性を得 られる。試行計算の結果， $\alpha=0.1$ まで十分な精度での計 算が可能なこと, 単純開口に相当する $\alpha>0.6$ の場合, 質 量保存が $10^{-3}$ のオーダで満足されるまでに必要な時間積 分は数十ステップ程度であり, 急峻な速度变化に対しても 十分追従できることを確認した ${ }^{[i \pm 1}$ 。

\section{3. 対象とした大空間構造物}

対象とした大空間構造物の概要を図 4 および表 1 に示 す。屋内ス夕ジアムとして最も多く採用される建筑物形状 は，蒲鈘型，半球型などのいわゆるドーム構造物である。 ここでは野球場としての使用が可能な規模としてアリーナ 部分での直径 $150 \mathrm{~m}$, 最高部天井高さ $80 \mathrm{~m}$ の半球型ドー 


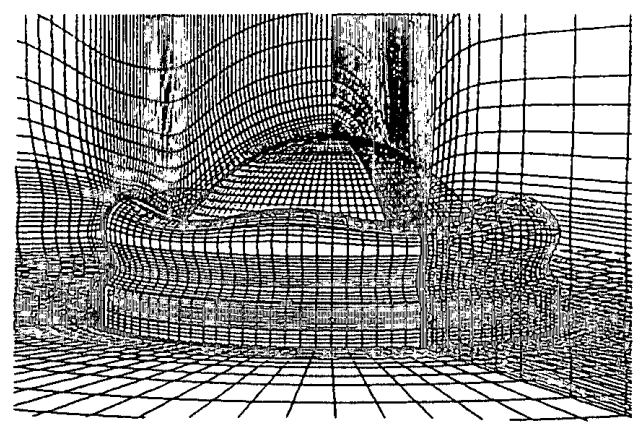

図 5 周辺気流の解析に用いた計算格子

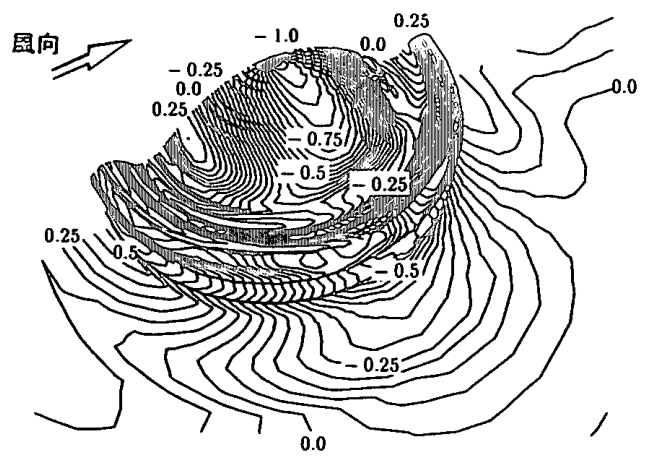

図 6 風圧係数分布の数値解析結界

ム構造の屋内スタジアムを想定した。観客席スタンドなど の配置を考虑すると，屋内容積は約 120 万 $m^{3}$ となる。な お本研究で対象としたドーム構造物は，その外周部にト一 ラス状の波形構造物を有しており，外部形状は比較的複雑 なものとなっている。

\section{4. 自然換気特性の検討}

\section{1 建築物周辺気流および風圧分布の特性}

予備的な検討として，開口を持たない場合の建筑物周辺 気流の状馝を数值解析した。解析に用いた計算格子を図 5 に示す。ここでは O 型グリッドと L 型グリッドとの組み合 わせにより計算格子を作成し，中央断面で分割した $1 / 2$ モ デルとして解析を行った。なお計算格子の生成には Trans Finite Interporation ${ }^{9}$ などの代数的手法を用い，綬い収束 条件のもとで Tompson ${ }^{10)}$ らの楕円形方程式による格子形 成法を併用して直交化と平滑化を行った。計算格子点数は $81 \times 55 \times 63$ である。境界条件として，領域の流入㑡境界 面には 0.27 乗プロファイルを設定して風洞実験の条件と 一致させ，すべての壁面，地表面には対数則壁関数による 境界条件を設定した。解析結果は建築物表面における压力 值を用いて次式により風圧係数として整理した ${ }^{[i \pm 6] 。 ~}$

$$
C_{p}=2 p / \rho u_{0}^{2}
$$

レイノルズ数 $R e=10^{5}$ について解析した風圧係数の分 布を図 6 に示す。解析結果は同時に実施した $1 / 200$ 模型に よる風洞実験結果とも定量的に一致しており，本研究で採 用した数值解析手法はある程度信頼できるものと判断し

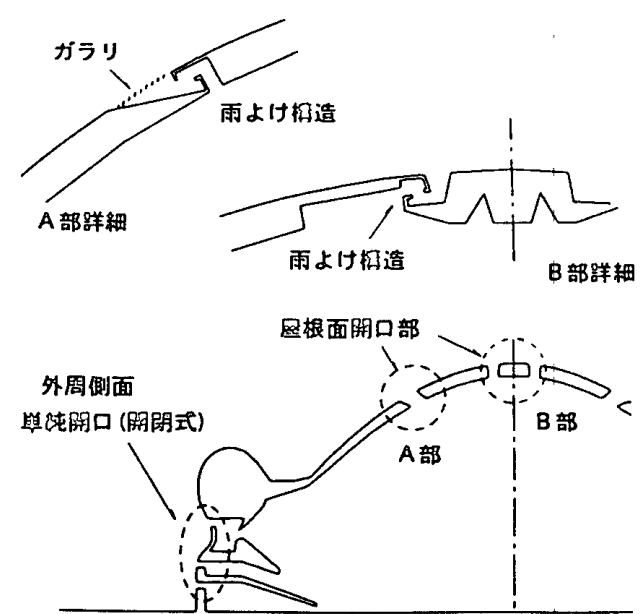

図 7 想定した開口の配置し形状

た。また対象建築物表面での風圧保数は，頂部から直径約 $80 \mathrm{~m}$ の籃囲でほぼ全域にわたり負の值を示すことがわかっ た。これはドーム形状の建築物を過ぎる流れが比較的表面 に沿って形成されるためと考えられる。なお，対象建筑物 の外周側面では風上側, 風下側ともに正値を持つ風圧保数 の極大点が認められた。風上側での極大値は対向流による もの，風下側での極大值は後流側での逆流に起因するもの と考えられる。

\section{2 開口部配置の設定}

予備解析の結果からは, 対象建筑物の屋根面頂部近傍お よび外周側面に開口を設けた構造とすると効率のよい自然 換気が得られるものと予測できる。ここでは図 $7 に$ 示すよ うに, 外周側面に高さ方向に 3 列, 屋根面に半径 $10 \mathrm{~m}$ お よび半傩 $35 m$ の 2 列の同心円状開口部を設定した。なお 屋根面の開口部には雨よけ構造を持つ固定式の開口を, 外 周側面の開口部には開閉式単純開口を想定した。

\section{3 想定した開口による自然換気の特性}

対象建築物に 4.2 節で示した開口を設けた場合につい て，自然換気の特性を数值解析により検討した。ここでは 対象建筑物内外の気流状㮩を同時に解析する必要があるた め，新たな解析モデルを作成した。解析領域は対象建築物 の直堡を $\mathrm{D}$ として幅方向 $3 \times D$, 主流方向 $8 \times D$, 高さ 方向 $5 \times \mathrm{D}$ の大きさを持つ立方体形状とし, 計算格子を $\mathrm{L}$ 型グリッドで作成した。解析領域全体の計算格子点数は $122 \times 84 \times 64$ である。なお主流方向の風上側には $2 \times D$, 風下側には $5 \times \mathrm{D}$ の領域をそれぞれ設けた。解析に用い たモデルの対象建築物近傍での計算格子を図 8 に示す。

屋根部の 2 列の開口部には, 先述したような雨よけ構

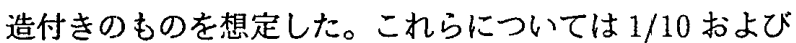
$1 / 60$ 部分模型を作成して風洞実験を実施し，その結果か ら流量係数 $(\alpha=0.27)$ を求好て解析に用いた。外周側面 開口部についてはすへて単純開口を想定し， $\alpha=0.65$ と した。なおここでは夏期に 5 万人の観客を収容し，座席空 調を用いて冷房した場合を想定することとし, 各部の温度 差に伴う熱対流効果を考慮した形で解析を行った。設定し た諸条件を表 2 に示す。 


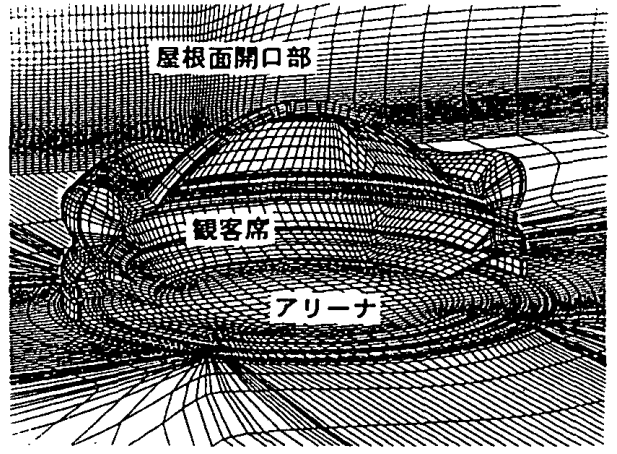

図 8 自然換気の検討に用いた計算格子

表 2 想定した設定条件

\begin{tabular}{|c|c|}
\hline 7 & 役定条件 \\
\hline 気象来件 & 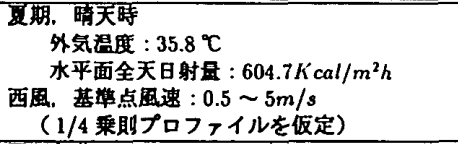 \\
\hline 内部発熱 & 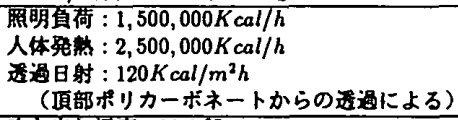 \\
\hline 空期条件 & 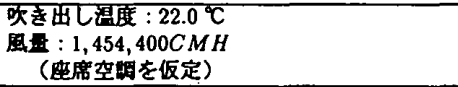 \\
\hline 開口条件 & $\begin{array}{l}\text { 量根面聞口部: } \alpha=0.27, \psi=0.25 \sim 0.5 \\
\text { 外周開口部: } \alpha=0.65, \psi=0.12 \sim 0.25\end{array}$ \\
\hline
\end{tabular}

数値解析により求めた屋内外の気流状態を図 9 に示す。 対象建築物の周辺には屋根面に沿った流れが形成されてお り，後流側には大規模な逆流領域が形成されている。また 外周部のトーラス状構造物周辺およびドームの頂部後方に は剥離が認められた。予備解析の結果からも予測されたよ うに，外周側面の開口部では風上側，風下側ともに外気が 流入しており，側面開口部は流入開口として作用すること がわかる。風上側，風下側開口部から屋内に流入した気流 はアリーナの中央付近で対向し，緩やかな上昇流に転じた 後, 屋根面の開口部から効果的に排気されている。屋根面 に設定した 2 列の開口部では，いずれもほぼ全周で流出方 向の気流が認められた。

上空 $30 \mathrm{~m}$ における風速を基準点風速とし, 風速を変化 させた場合の換気特性を比較した。ただし外周側面に設定 した開口部では，流入部分と流出部分とが混在する。ここ では屋根面開口部での流出流量を用いて，屋内の平均換気 回数 $N_{v}^{*}$ を次式のように評価した[注7]。

$$
N_{v}^{*}=\sum_{i=I 1}^{I 2} \sum_{j=J 1}^{J 2} Q_{i, j, K 2+1 / 2}^{o u t} / V_{0}
$$

空間内に適当な局所領域を想定した場合，この部分への流 入，流出フラックスの絶対值の総和は換気流量の 2 倍とな る。上下スタンドの観客席およびアリーナから高さ $3 m$ ま での項域を居住域と定義し，居住域での局所的な換気特性 についても評価を行った。座席空調により供給される機械 換気を除外すると，居住域での換気回数 $N_{v}$ は次式で評価 できる。

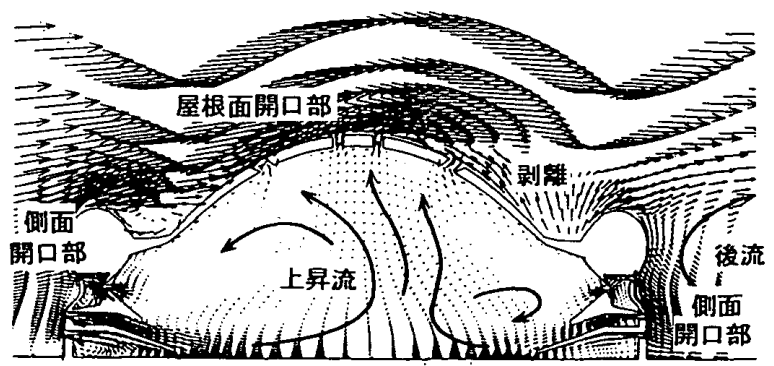

図 9 屋内外気流状態の数値解析結果

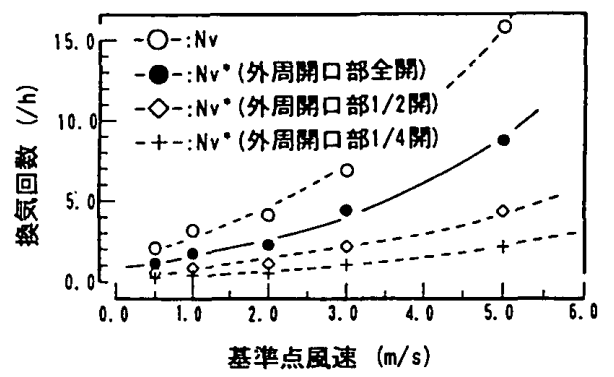

図 10 開口条件による換気回数の変化

$$
\begin{aligned}
N_{v}= & {\left[\frac { 1 } { 2 } \left\{\left|\sum_{j=J 1}^{J 2} \sum_{k=K 1}^{K 2}\left(U_{I 1-1 / 2, j, k} S_{I 1-1 / 2, j, k}\right)\right|\right.\right.} \\
& +\left|\sum_{j=J 1}^{J 2} \sum_{k=K 1}^{K 2}\left(U_{I 2+1 / 2, j, k} S_{I 2+1 / 2, j, k}\right)\right| \\
& +\left|\sum_{i=I 1}^{I 2} \sum_{k=K 1}^{K 2}\left(V_{i, J 1-1 / 2, k} S_{i, J 1-1 / 2, k}\right)\right| \\
\left.\left.+\left|\sum_{i=I 1}^{I 2} \sum_{k=K 1}^{K 2}\left(W_{i, j, K 2+1 / 2} S_{i, j, K 2+1 / 2}\right)\right|\right\}-Q_{A C}\right] & / V_{\text {res }}
\end{aligned}
$$

外周側面の開口部を全開とした場合， $1 / 2$ 開放した場合， $1 / 4$ 開放した場合の 3 種類の条件について解析した換気回 数の変化を図 10 に示す。なお図に併記した居住域換気回 数は，側面開口部を全開とした場合の值である。外周側面 の開口部を全開とした場合には，風速 $3 \mathrm{~m} / \mathrm{s}$ の場合でも 換気回数 4.5 回/ $h$ 程度が得られており，ある程度の風が ある日にはファン動力なしで十分な換気を得られることが わかった。な权容人員ひとりあたりの二酸化炭素放出量 を $200 \mathrm{ml} / \mathrm{min}$ ，外気濃度を $300 \mathrm{ppm}$ として，このときの 居住域での二酸化炭素濃度を計算すると，5万人収容時の 平均濃度は約 $320 p p m$ であり，ビル管理法の空気污れ指標 $(1000 p p m \text { 以下 })^{11)}$ を自然換気のみで十分満足できること を確認した。

\section{5. 外部気流を利用した場合の屋内温熱特性}

5.1 外部気象条件の選定とそのモデル化

外気の取込みによる自然換気は，必ずしも屋内の温熱環 境制御に寄与するものとは限らない。ここでは季節ごとの 
表 3 解析に用いた各月の気象条件

\begin{tabular}{|c|c|c|c|c|c|c|c|}
\hline & 4月 & & & $n$ & 0 & & 0 \\
\hline & 19.5 & 21.3 & 25.5 & 31.4 & 35.2 & $\overline{31.5}$ & \\
\hline 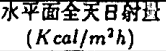 & 689 & 714 & 428 & 739 & 682 & 427 & \\
\hline
\end{tabular}

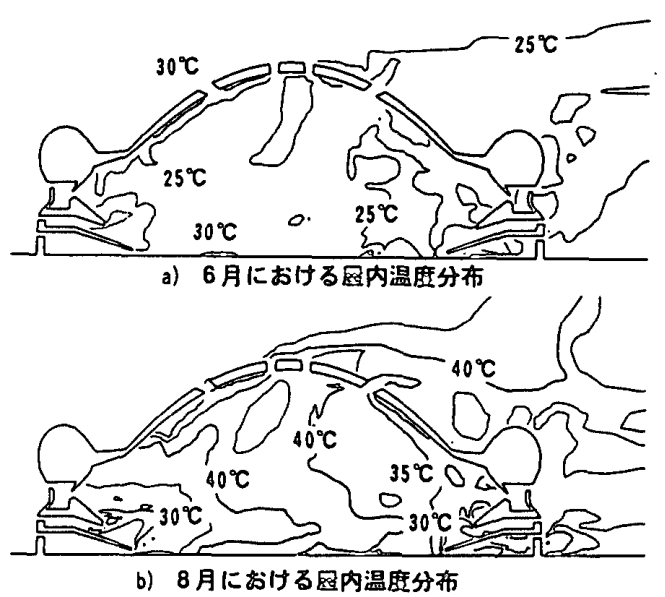

図 116 月および8月における屋内温度分布

外部気象条件を想定し，外気温度や日射量が異なる場合の 温熱環境の違いを比較した。

冬期には外気温度か屋内空調温度よりもかなり低くなる ことが予想され，外気を導入する利点は少ない。ここでは 夏期から中間期にかけての特性を考察することとし，4月 から 10 月までの睛天日の午後 1 時における条件について 解析を行った。想定した外部気象条件を表 3 に示す。日射 による取得熱量は，想定した建設予定地の緯度，経度 (北 稦 $34^{\circ} 4^{\prime}$, 東経 $135^{\circ} 3^{\prime}$ ), 建筑物外表面の各セル界面につ いての方位角，傾斜角を考慮して求め，相当外気温度に換 算した上，熱貫流率を用いて境界条件に与えた。なお水平 面全天日射量からの直散分離には木村，宇田川による推定 式12)を用いた。

ここでは 4.3 節と同様, 屋内に 5 万人の観客を収容し，
座席空調を併用した場合を想定した。空調吹き出し温度は

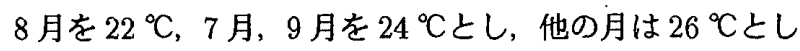
たが，その他の条件については表 2 と同様の設定とした。 いずれの場合も外周側面の開口部は全開としている。

\section{2 斈節ごよの屋内温熱特性}

基準点風速を $2 \mathrm{~m} / \mathrm{s}$ とした場合の，6月および 8 月にお ける屋内温度分布を図 11 に示す。いずれの場合も屋内上 部で高温となる温度勾配が怨められるが，日射量の大きい 8 月の条件では特に, ドーム中央部から天井面にかけて高 温の領域が形成されている。対象建築物内部を7層に分割 し, 各層の平均温度として垂直方向の屋内温度分布を比較 した結果，それぞれの条件における上下温度差は 6 月の場

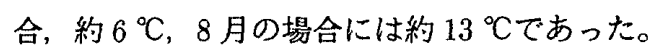

図 12 は 4 月から 10 月までの屋内温熱環境を各層での 平均温度の垂直方向分布として比較したものである。なお ここでは，外周側面の開口を閉じた場合についても同様の 解析を実施し，その結果を併記した。観客席とアリーナの ある居住域は床面から $26 m$ までの領域である。

外周側面の開口を閉じた場合には，いすれれの場合も屋内 の上部に熱だまりを生じるが，開口を開けて外気を取込ん だ場合には，屋内温熱環境は季節によって大きく変化する ことがわかる。7月から 9 月にかけては外気温度が高いた め, 外気を導入すると居住域温度か上昇し, 空調制御か困 難となることが予测される。しかし 4 月から 6 月および 10 月の中間期には，自然換気によって熱だまりが勃果的 に除去されており，外気尊入の効果が期待できる。

夏期および中間期の気象条件について基準風速を変化さ せた場合の影響を比較した。夏期気象条件として 8 月の条 件を，また中間期気象条件として6月の条件を用いて解析 した結果を図 13 に示す。夏期条件では風速の增加に伴っ て居住域温度か上昇する上, 風速 $5 \mathrm{~m} / \mathrm{s}$ 以内の範囲では屋 内上部での熱だまりを除去する効果はあまり認められな
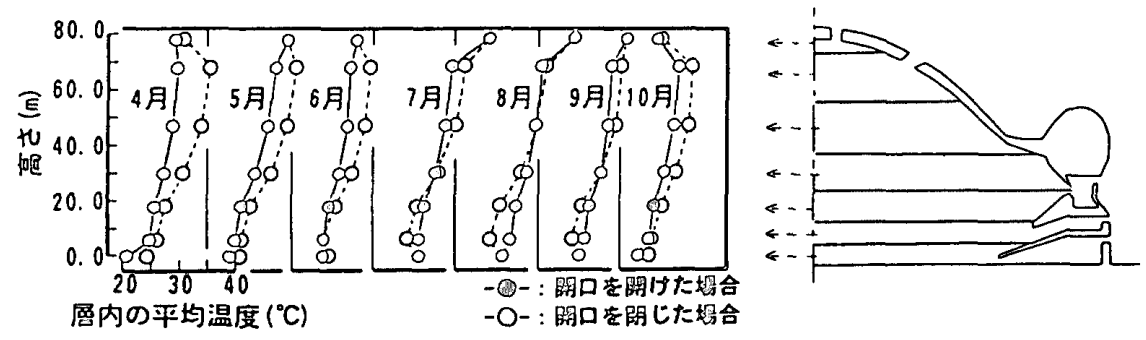

図124月から12月までの屋内の垂直温度分布

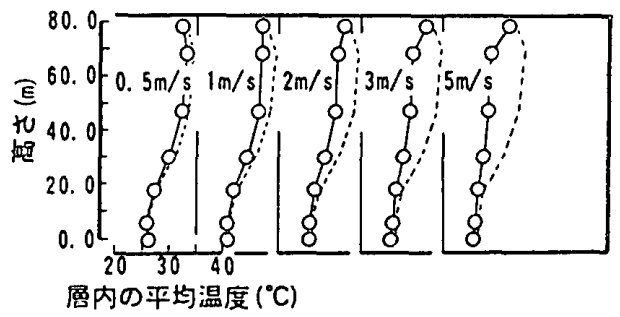

a）6月の然件定作定した的含

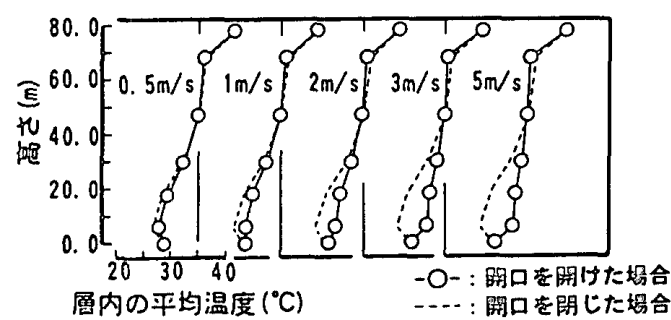

b）8月の㖓件を饭定した奶合

図 13 風速による屋内垂直温度分布の変化 
い。一方中間期には，風速の増加に伴って熱だまりを除去 する効果は増大しており, 風速 $3 \mathrm{~m} / \mathrm{s}$ 以上の場合には高さ $30 \sim 70 \mathrm{~m}$ の領域での温度差は $2 \sim 3{ }^{\circ} \mathrm{C}$ 程度以内に抑えら れることがわかった。また中間期には外気温度が居住域の 空調設定温度に近い值となるため, 風速か変化しても居住 域温度は大きく変化していない。気流条件と外気温度条件 が適当な範囲にある場合には，自然換気のみで屋内温熱環 境の制御を行うことも可能と考えられる。

\section{6. まとめ}

半球型ドーム構造の大規模屋内スタジアムを対象として, 外部気流を利用した自然換気方式の可能性を検討した。解 析にはスタッガート変数配置一般曲線座標系による乱流解 析手法を用い, 流体の運動量方程式とエネルギー方程式と を連成して浮力効果を再現した。また開口部の表現として 開口面積比と通風特性とをモデル化して屋内外の気流状態 を同時に解析した。

数值解析によりドーム周辺気流, ドーム内の自然換気特 性および夏期から中間期にかけての屋内温熱特性について 考察した結果，以下の知見を得た。

(1) 半球型ドーム構造では, 周包気流により頂点付近に比 較的広い負圧領域か，また風上側，風下側側面には正値 を有する風压の極大点を生じる。

(2) ドームの屋根面と側面とに開口部を設けた場合, 周扨 気流の影響で効果的な自然換気が得られる。このとき, 側面開口部は流入開口，屋根面開口部は流出開口として 作用する。

(3) 本研究で対象とした構造では，風速 $3 \mathrm{~m} / \mathrm{s}$ の場合に約 4.5 回 $/ h$ の換気回数が得られ，本構造ではある程度風 のある日にはファン動力なしで十分な換気を得られるも のと予測できる。

(4) 自然換気による外気導入の効果は, 中間期において特 に期待でき，これにより屋内上部に発生する熱だまりを 除去することができる。

本研究により，大空間構造物への自然換気方式の採用が可 能なこと，自然換気による外気の導入が特に中間期にお ける屋内温熱環境制御に効果的なことなどが明らかとなっ た。外気導入を併用した空調システムでは，空調消費エネ ルギーを大幅に削減することも可能と考えられ，外部気象 条件に合わせた開口部の開閉制御方法や，エネルギー的な 側面からの検討も今後必要になるものと思われる。

記 号

\begin{tabular}{|c|c|}
\hline$C_{p}$ & : 定王比熱 \\
\hline$C_{p 0}$ & : 風王係数 \\
\hline $\begin{array}{l}C_{\mu}, C_{1}, C_{2}, C_{3} \\
f^{u_{i}}\end{array}$ & 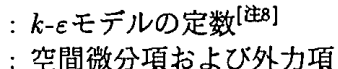 \\
\hline$F, \mathbf{F}$ & : セル界面でのフラックス \\
\hline$F^{C}$ & :Fの対流成分 \\
\hline$F^{D}$ & : $F$ の拡散成分 \\
\hline$g_{i}, g$ & : 重力加速度 \\
\hline$g^{u_{i}}$ & : 圧力勾配項 \\
\hline
\end{tabular}

\begin{tabular}{|c|c|}
\hline$h$ & : エンタルピー \\
\hline$I 1, I 2, J 1$ & : 対象領域を規定するセル \\
\hline$J 2, K 1, K 2$ & : インテックスの始点, 終点 \\
\hline$J$ & : 変換の Jacobian \\
\hline$k$ & : 乱流エネルギー \\
\hline$n$ & : 時間ステップ \\
\hline $\mathbf{n}$ & : 界面の法線方向単位ベクトル \\
\hline$N_{v}$ & : 対象領域内の局所的な換気回数 \\
\hline$N_{v}^{*}$ & : 屋内の平均換気回数 \\
\hline$p$ & : 圧力 \\
\hline$p_{0}$ & : 状態方程式の基準圧力 \\
\hline Prt & : 乱流 Prandtl 数 \\
\hline$\dot{Q}$ & : 発熱量 \\
\hline$Q_{A C}$ & $\begin{array}{l}\text { : 空調により対象量域内に供給 } \\
\text { される風量 }\end{array}$ \\
\hline$Q^{\text {out }}$ & : 屋根面開口部からの流出流量 \\
\hline$Q_{t r}$ & ：通風量 \\
\hline$R_{i}$ & : 抵抗力 \\
\hline $\begin{array}{l}S_{i \pm 1 / 2, j, k} \\
S_{i, j \pm 1 / 2, k}\end{array}$ & $\begin{array}{l}\text { : セル }(i, j, k) \text { における各セル } \\
\text { 界面の面積 }\end{array}$ \\
\hline$S_{i, j, k \pm 1 / 2}$ & \\
\hline$t$ & ：時間 \\
\hline$T$ & : 温度 \\
\hline$u_{0}$ & $\begin{array}{l}\text { ：基準点高さ (地上 } 30 \mathrm{~m} \text { ) } \\
\text { における風速 }\end{array}$ \\
\hline$u_{i}$ & $\begin{array}{l}: \text { 物理空間の速度 } \\
\qquad\left(u_{1}, u_{2}, u_{3} \text { or } u, v, w\right)\end{array}$ \\
\hline$U_{i}$ & $\begin{array}{l}\text { : 反変速度 } \\
\quad\left(U_{1}, U_{2}, U_{3} \text { or } U, V, W\right)\end{array}$ \\
\hline$U^{C}, V^{C}, W^{C}$ & ：反変速度の補正量 \\
\hline$U^{*}, V^{*}, W^{*}$ & : 反変速度の仮定値 \\
\hline$V_{0}$ & : 屋内の総内部容積 \\
\hline$V_{\text {res }}$ & : 対象領域の容積 \\
\hline$x_{i}$ & $\begin{array}{c}\text { : 物理空間の座標 } \\
\left(x_{1}, x_{2}, x_{3} \text { or } x, y, z\right) \\
\text {. 法量任断 }\end{array}$ \\
\hline $\begin{array}{l}\alpha \\
\alpha_{p}\end{array}$ & $\begin{array}{l}\text { : 流量係数 } \\
\text { : 王力補正式の緩和係数 }\end{array}$ \\
\hline$\delta p$ & : 王力の補正量 \\
\hline$\Delta p$ & : 開口前後における圧力差 \\
\hline$\Delta t$ & : 時間ステップ幅 \\
\hline$\varepsilon$ & : エネルギー散逸率 \\
\hline$\gamma$ & : 空気の比重量 \\
\hline$\gamma_{c}$ & : 比熱比 \\
\hline$\Gamma$ & $\begin{array}{c}\text { : 拡散項の係数に関する } \\
\text { 一般化表示 }\end{array}$ \\
\hline$\mu$ & ：分子粘性係数 \\
\hline $\begin{array}{l}\mu_{T} \\
\phi\end{array}$ & ：乱流粘性係数 \\
\hline $\begin{array}{l}\phi \\
\psi\end{array}$ & ：独立変数の一般化した表示 \\
\hline $\begin{array}{l}\psi \\
\rho\end{array}$ & : セル界面での開口率 \\
\hline$\langle\rho \phi\rangle$ & : 密度 \\
\hline$\lambda$ & : 熱伝導率 \\
\hline $\begin{array}{l}\sigma_{k}, \sigma_{\epsilon}, \sigma_{T} \\
\xi_{i}\end{array}$ & $: k-\varepsilon$ モテルの定数 [注8] \\
\hline$\xi_{i}$ & $\begin{array}{l}: \text { 計算空間の座標 } \\
\quad\left(\xi_{1}, \xi_{2}, \xi_{3} \text { or } \xi, \eta, \zeta\right)\end{array}$ \\
\hline
\end{tabular}

注

[注 1] Jacobian の定義については，文献により計算空間から物 理空間への変換を定義する場合とその逆の場合とがある。本 論文では前者の定義に統一した。

[注 2] 屋内温熱環境の解析で多用されている一般的なブシネ近 似では，浮力項の評価に用いられる参照温度が解析対象領域 内で一定の值となる。このため温度成層内での浮力効果は， 同レベルでの周辺温度差から生じる効果よりも過剩に評価さ れることとなる。この方法は対象領域が完全な閉鎖空間の場 
合には，上昇流が天井面により拘束されるため妥当な結果を 与えると考えられるが，本研究で対象とする系は天井部に開 口を有しており，ブシネ近似の採用は妥当でないと判断した。 [注 3] その意味で，想定した基䃈方程式系には圧縮性を考虑 していることとなるが，後述するように各時刻での収束計算 において密度榇化は定数として扱われるため，通常の非王縮 性流体の場合とほぼ同様の扱いとなる。

[注 4] MAC 系のアルゴリズムでは一般にこの方法が採られる。 本手法でも時間微分項を陽的に展開しているのでCourant 条件を満足するよう $\Delta t$ を設定する必要があり，諸量の時間 的なずれについては大きな問題は生じないと思われる。

[注 5] 通風特性のモテル化に関して試行計算を行った。ここで は単純な 1 次元問題を想定し，領域中央のセル界面に本モテ ルを設定して一方向流を形成させた。(1)〜 (7) に示した基 整方程式は，温度一定の条件では完全な非王縮性流体となる。

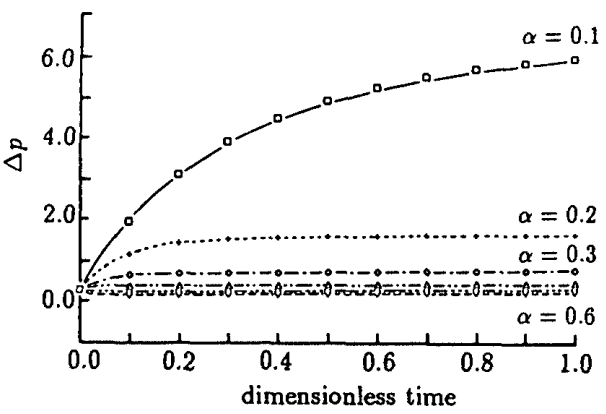

a) $\Delta \mathrm{P}$ の立上がり待神

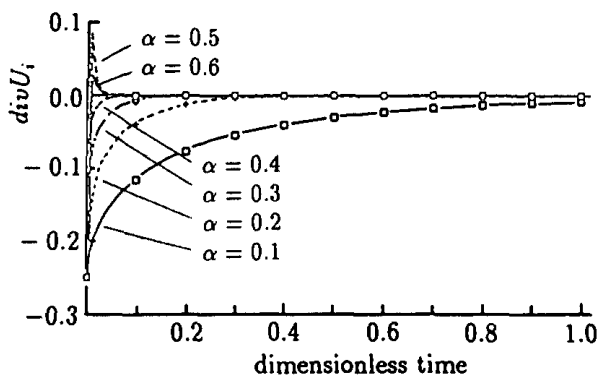

b) $\operatorname{div} U$ 、の立上がり侍珄

補図 $1 \Delta p$ の立上がり特性

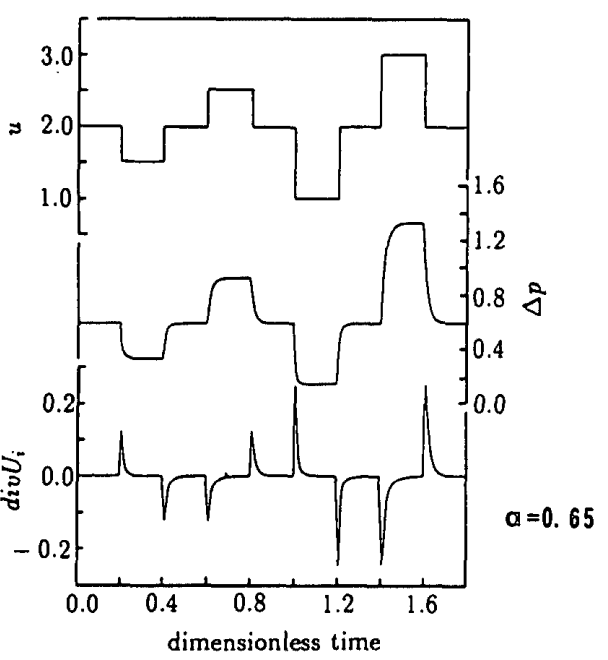

補図 2 急俩な速度変化に対する $\Delta p, \operatorname{div} U_{i}$ の追従禇
スパン方向の領域幅が一定の 1 次元問題では領域内の速度が 一様となり，モテルを設定したセル界面の前後には $(27)$ 式 に相当する圧力差が生じるはずである。

補図 1 は流量係数 $\alpha$ を 0.1 から 0.6 まで変化させたときの $\Delta p$ 方よび $\operatorname{div} U_{i}$ の時間变化を計算した結果である。質量保 存は時間積分にしたがって満足されることとなるため，立上 がり直後に大きく振れる $\operatorname{div} U_{i}$ は，時間ステップの進行に伴 い 0.0 に漸近している。 $\alpha$ が小さくなると divUiおよび $\Delta p$ の立上がりは遅くなるが，これにより開口前後での压力勾配 の急唆な立上がりが綬和され，計算を安定させる効果が得ら れるものと考えられる。

補図 2 は流入流速を $1.0 \sim 3.0 \mathrm{~m} / \mathrm{s}$ の間でステップ的に変 化させた場合の $\Delta p$ および $\operatorname{div} U_{i}$ の追従性を示したものであ る。压力の変化は急峻な速度変化によく追従しており，div $U_{i}$ $\simeq 0.0$ の時点での $\Delta p$ はいずれも $(27)$ 式を満足している。

本諭文の解析には $\alpha=$ const. 仮定したが，通風量変化に 伴い $\alpha$ が变化するようなモデルを用いる場合には，本手法が 有効と考えられる。

[注 6] 本研究では，スタッガード格子系を採用しているため, 建築物表面での压力值は評価されていない。ここでの風圧係 数の算出は傾问を把握するための予備計算的な意味で行った ものであるため、表面に荈接するセル中心の値を用いて計算 した。

[注 7] 数值解析の結果, 側面開口部から流入した外気の一部は 屋内換気に関与せずそのまま流出することがわかった。屋内 換気に関与するものの多くは屋根面の開口部から排気される こととなるので，ここでは換気回数の評伍として便宜的に屋 根面開口部での流出流量を用いた。

[注 8] 本研究で用いた $k-\varepsilon$ モデルの定数は以下のとおりである。

$$
\begin{aligned}
C_{\mu} & =0.09, \quad C_{1}=1.44, \quad C_{2}=1.92, \\
C_{3} & =\left\{\begin{array}{ll}
1.44 & \left(G_{T}>0.0\right) \\
0.0 & \left(G_{T} \leqq 0.0\right)
\end{array},\right. \\
\sigma_{k} & =1.0, \quad \sigma_{\epsilon}=1.3, \quad \sigma_{T}=0.9
\end{aligned}
$$

\section{参考文献}

1）宮川：变分原理を用いた大空間の上下温度分布の計算法，空 気調和衛生工学会論文集, 13 (1990), 1.

2) 戸河里, 荒井, 三浦 : 大空間の空調・熱環境計画手法の研 究，日本建築学会計画系論文報告集，427 (1991)，9.

3) 石田, 宇田川：上下温度分布を考虑した熱負荷計算, 空気調 和衛生工学会学術講演論文集, (1992), 77 .

4) 村上, 加藤, 近藤, 近本 : 大空間の温熱空気環境に関する数 值シミュレーション，生産研究，42, 7 (1990), 413.

5) 加藤, 村上, 羽生, 曾：対流・放射連成解析による大規模了 トリウム空間の温熱環境解析，第 8 回数値流体力学シンポジ ウム講演論文集 (1994), 177.

6) Launder, B.E. and Spalding, D.B. : Mathematical Models of Turbulence, Academic Press (1972).

7) Leonard, B.P. : A Stable and Accurate Convective Modeling Procedure Based on Quadratic Up-stream Interpolation, Comput. Methods Appl. Mech. Eng., 19 (1979), 59

8) Patankar, S.V. : Numerical Heat Transfer and Fluid Flow, Hemisphere Publishing Corp. (1980).

9) Knupp, P. and Steinberg, S. : Fundamentals of Grid Generation, CRC Press (1993).

10) Thompson, J.F. : Numerical Grid Generation, North Holland (1982)

11) 古賀：ビル衛生管理法, 帝国地方行政会 (1971), 40 .

12) 宇田川, 木村 : 水平面全天日射量観測值よりの直達日射量 の推定，日本建築学会論文報告集，267 (1978)，83.

（1995年7月10日原稿受理，1995年10月31日採用決定） 